\title{
The multicolored Asian ladybeetle Harmonia axyridis (Coleoptera: Coccinellidae) in Quebec agroecosystems ten years after its arrival
}

\author{
Éric LUCAS ${ }^{1}$, Charles VINCENT ${ }^{2}$, Geneviève LABRIE ${ }^{*}$, Gérald CHOUINARD $^{3}$, François FOURNIER ${ }^{4}$, Francine \\ PELlETIER ${ }^{1}$, Noubar J. BOSTANIAN ${ }^{2}$, Daniel CODERRE ${ }^{1}$, Marie-PierRe MIGNAULT ${ }^{5}$ and PierRe \\ LAFONTAINE $^{6}$
}
${ }^{1}$ Groupe de Recherche en Écologie Comportementale et Animale (GRECA), Département des Sciences Biologiques, Université du Québec à Montréal, C.P. 8888 Succ. "Centre-ville”, Montréal, Qc, Canada H3C 3P8; e-mail: lucas.eric@uqam.ca / daniel.coderre@uqam.ca
${ }^{2}$ Centre de Recherche et de Développement en Horticulture, Agriculture et Agro-alimentaire Canada, 430 Boul. Gouin, Saint-Jean-sur-Richelieu, Qc, Canada J3B 3E6; e-mail: vincentch@agr.gc.ca / bostaniannj@agr.gc.ca
${ }^{3}$ Institut de Recherche et de Développement en Agroenvironnement, 3300 Sicotte, Saint-Hyacinthe, Qc, Canada J2S 7B8; e-mail: gerald.chouinard.irda.qc.ca / francine.pelletier@irda.qc.ca
${ }^{4}$ Insecterra, 2300 Sherbrooke Est, bureau 4, Montréal, Qc, Canada H2K 1E5
${ }^{5}$ Département de Phytologie, Université Laval, Sainte-Foy, Qc, Canada G1K 7P4
${ }^{6}$ Centre de Valorisation des Plantes, Carrefour Industriel et Expérimental de Lanaudière, 801 route 344, C.P. 3158, L'Assomption, Qc, Canada J5W 4M9

Key words. Coccinellidae, exotic species, invasion, multicolored Asian ladybeetle, Harmonia axyridis, Coccinella septempunctata, Propylea quatuordecimpunctata, Coleomegilla maculata lengi, agroecosystems, vineyard, apple, corn, sweet pepper, lettuce

\begin{abstract}
The multicolored Asian ladybeetle, Harmonia axyridis (Coleoptera: Coccinellidae), was first reported in southern Canada in 1994. In this study, we examined the status of the ladybeetle in Quebec agroecosystems seven to ten years after its arrival. We integrated the findings from eight independent field studies carried out in pome fruit, grapes, medicinal crops, field corn, sweet corn, sweet pepper, lettuce, and soybean. Nine aphidophagous and 6 coccidophagous coccinellid species were sampled on these crops. Among these aphidophagous species, three invasive (H. axyridis, Coccinella septempunctata and Propylea quatuordecimpunctata) as well as one indigenous species (Coleomegilla maculata lengi) were consistently present. Higher richness was observed in perennial crops, where the 6 coccidophagous coccinellids were almost exclusively present. Higher abundance of aphidophagous coccinellids was observed in field and sweet corn. The multicolored Asian ladybeetle was a dominant species of the coccinellid assemblage in all crops monitored.
\end{abstract}

\section{INTRODUCTION}

Biological invasions usually occur in three successive stages, (1) transport of the invader to the target area, (2) establishment and growth of invasive populations, and (3) dispersion of the invader into adjacent areas (Shea \& Chesson, 2002). The complexity of trophic interactions in the recipient ecosystem is one of the main opposition factors of the ecosystem to the invasion. This is because it is more difficult to get established in a complex food web than in a simpler one (Hewitt \& Huxel, 2002; Shea \& Chesson, 2002; Stachowicz et al., 2002). Based on the availability of plant resources and the limited number of trophic links, agro-ecosystems are highly susceptible targets for biological invasions.

In 1994, the multicolored Asian ladybeetle, Harmonia axyridis (Pallas) (Coleoptera: Coccinellidae), was first recorded in Canada by Coderre et al. (1995). It is an east palearctic species that had been introduced in Hawaii and California in 1916, 1964 and 1965 and East of the Mississipi (USA) in 1978 and 1982 (Gordon, 1985; Tedders \& Schaefer, 1994). It is now well established throughout
North America (Chapin \& Brou, 1991; Gordon \& Vandenberg, 1991; Tedders \& Schaefer 1994; ColungaGarcia \& Gage, 1998; Turnock et al., 2003). Harmonia axyridis is an aphidophagous coccinellid that shows highly polyphagous habits (Iablokoff-Khnzorian, 1982; Hodek \& Honěk, 1996; LaMana \& Miller, 1996; Lucas et al., 1997, 1998, 2004, 2007; Koch, 2003; Pervez \& Omkar, 2006). In the USA, $H$. axyridis has established itself on numerous crops (LaMana \& Miller, 1996; Colunga-Garcia \& Gage, 1998; Michaud, 2002; Brown, 2003; Musser \& Shelton, 2003; Snyder et al., 2004; Bacon, pers. comm.). In Quebec, Canada, this coccinellid has been collected regularly in the St-Lawrence basin and is now encountered further North around St-Jean Lake $\left(48^{\circ} 25^{\prime} \mathrm{N}, 71^{\circ} 5^{\prime} \mathrm{W}\right)$ (Labrie, pers. obs.) and in the Abitibi region $\left(48^{\circ} 30^{\prime} \mathrm{N}, 77^{\circ} 47^{\prime} \mathrm{W}\right)$ (Laplante, pers. comm.). This eurytopic species is found in different agro-ecosystems such as forests, swamps and even urban areas (Koch, 2003; Majerus et al., 2006; Pervez \& Omkar, 2006; Labrie et al., 2007). Furthermore, $H$. axyridis extends its northern distribution by using human houses as overwin-

\footnotetext{
* Corresponding author; e-mail : genevievelabrie@yahoo.ca
} 
tering sites, benefiting from a cold-free space (Labrie et al., 2007).

Harmonia axyridis is thought to affect indigenous ladybeetle species either by exploitative competition or by intraguild predation (Hironori \& Katsuhiro, 1997; Yasuda \& Ohnuma, 1999; Dixon, 2000; Kajita et al., 2000; Yasuda et al., 2001; Michaud, 2002; Snyder et al., 2004; Lucas et al., 2007). Its establishment was followed by important decreases in natural populations of several local ladybeetle species such as Brachiacantha ursina (Fabricius), Cycloneda munda (Say) and Chilocorus stigma (Say) (Colunga-Garcia \& Gage, 1998). In recent years, Quebec agroecosystems have been invaded by two other coccinellids, Propylea quatuordecimpunctata L., probably in the 1960s (Gordon, 1985) and Coccinella septempunctata L. in 1973 (Larochelle, 1979). These ladybeetles, particularly $C$. septempunctata, have also earlier affected coccinellid assemblages, reducing abundance of indigenous species such as Coccinella transversoguttata richardsoni Brown, Adalia bipunctata L., Coccinella novemnotata Herbst and Hippodamia convergens Guérin-Méneville (Wheeler \& Hoebeke, 1995; Elliott et al., 1996; Ellis et al., 1999; Evans, 2004).

Seven to ten years after its arrival in Eastern North America, this study examines the relative abundance of the multicolored Asian ladybeetle and other coccinellid species in three perennial and five annual crops of southern Quebec.

\section{MATERIAL AND METHODS}

\section{Pome fruit}

The study was carried out in 1999 and 2000 in an organic apple orchard (planted in 1986) in Henryville $\left(45^{\circ} 8^{\prime} \mathrm{N}\right.$, $73^{\circ} 11^{\prime} \mathrm{W}$ ), Quebec, Canada. In both years, adult coccinellid populations were assessed from May to August by white sticky traps and by tapping apple trees on the third and sixth peripheral rows of the orchard. Tapping was done weekly over a $1 \mathrm{~m}^{2}$ cloth placed under a series of 20 apple trees. For each tree, eight branches were tapped three times. Branches were selected in the four cardinal points at $50 \mathrm{~cm}$ and $150 \mathrm{~cm}$ from the ground. Ten white sticky traps were also placed at these two distances from the ground on apple trees. Once a week, traps were observed and coccinellid species identified.

\section{Grapes}

The study was carried out from 2000 to 2002 in two commercial vineyards (both of 0.7 ha and planted in 1983-84) in southern Quebec, Canada. Located in Dunham $\left(45^{\circ} 07^{\prime} \mathrm{N}\right.$, $72^{\circ} 51^{\prime} \mathrm{W}$ ), the L'Orpailleur vineyard comprised only vines of the cultivar White Seyval. The Dietrich Jooss vineyard was located in Iberville $\left(45^{\circ} 16^{\prime} \mathrm{N}, 73^{\circ} 11^{\prime} \mathrm{W}\right)$, and it comprised De Chaunac, Cayuga White and White Seyval cultivars. A two-liter plastic container was held below a berry cluster and the cluster was tapped twice. Coccinellids fallen into the container were identified, counted, and then released in the vineyard. Each week from June to mid-September, 100 grapevines (50 "De Chaunac" and 50 "Cayuga White") were sampled at random at the Dietrich Jooss vineyard and 100 "White Seyval" grapevines were sampled at random at L'Orpailleur. Coccinellid adults were sorted out in the laboratory, identified and tallied. Voucher specimens were deposited at the Eastern Cereal and Oilseeds Research Centre, Agriculture and Agri-Food Canada, Ottawa,
Canada. Except for fungicides, no insecticides were used in the plot where coccinellids were collected (Bostanian et al., 2003).

\section{Medicinal crops}

From the end of May to mid-September 2003, four medicinal crops, Achillea millefolium Linnaeus, Valeriana officinalis Linnaeus, Hypericum perforatum Linnaeus and Echinacea purpurea (Linnaeus) Moench, were sampled weekly in fields located at L'Assomption $\left(45^{\circ} 50^{\prime} \mathrm{N}, 73^{\circ} 25^{\prime} \mathrm{W}\right)$, Quebec, Canada. The crops had been planted in 2002. Each field was divided in 36 sections, $5 \mathrm{~m}$ apart of each other and of other plant species. In each section, two plants were examined visually each week for coccinellid eggs, larvae and adults.

\section{Sweet corn}

During the summer 2000 and 2001, a corn field of the D'Artagnan cultivar was sampled from the beginning of July to the end of August. The field was located in Saint-Hyacinthe $\left(45^{\circ} 37^{\prime} \mathrm{N}, 72^{\circ} 57^{\prime} \mathrm{W}\right)$, Quebec, Canada. It was divided into eight sections with 10 sampling stations in each section. Visual observations of coccinellids were done weekly on five plants, near the 10 sampling stations. Adults, larvae and eggs of coccinellids were identified and counted.

\section{Field corn}

The study was done in three commercial corn fields in Farnham and 1'Ange-Gardien $\left(45^{\circ} 24^{\prime} \mathrm{N}, 72^{\circ} 44^{\prime} \mathrm{W}\right)$, Quebec, Canada, in 2002 and 2003. During the summer, the fields were sampled seven times from the beginning of August to midOctober. In the center of each field, 30 plants were randomly selected and inspected for the presence and abundance of aphids and coccinellids. Eggs and early instars of coccinellids were brought to the laboratory and reared to the adult stage in an incubator $\left(25^{\circ} \mathrm{C}, 65 \%\right.$ R.H. and $16 \mathrm{~L}: 8 \mathrm{D}$ photoperiod) to be identified to the species.

\section{Sweet pepper}

The study was done in a field located in Laval $\left(45^{\circ} 30^{\prime} \mathrm{N}\right.$, $\left.73^{\circ} 32^{\prime} \mathrm{W}\right)$, Quebec, Canada. It was sampled two times per week from early July to mid-August 2002. Each sample consisted of 50 plants randomly selected and visually inspected. The presence and abundance of aphids and coccinellids were recorded.

\section{Lettuce}

From mid-May to mid-September 2002, 25 fields of head lettuce, romaine and leaf lettuce were sampled. The fields were located in Sherrington $\left(45^{\circ} 10^{\prime} \mathrm{N}, 73^{\circ} 31^{\prime} \mathrm{W}\right)$, Quebec, Canada. Each two weeks, five samples per 0.4 ha were randomly selected and visually examined for coccinellid abundance.

\section{Soybean}

The study was carried out in 10 soybean fields in two agricultural areas near Quebec City (from $45^{\circ} 11^{\prime} \mathrm{N}$ to $46^{\circ} 44^{\prime} \mathrm{N}$, from $70^{\circ} 57^{\prime} \mathrm{W}$ to $74^{\circ} 23^{\prime} \mathrm{W}$ ), Quebec, Canada, between June and August 2002 and 2003. Samples were collected every two weeks by one to two hauls of sweep net in 10 zones in each field on the upper vegetation. Insects collected were brought to the laboratory for identification. Only adult coccinellids were identified.

\section{Statistics}

As the eight crops under study had different agronomic and ecological conditions, only intra-crop statistical analysis were performed. In crops where more than one year of data was available, a contingency Table (G test) compared the relative proportions of the different species of coccinellids as well as the proportion of invasive versus indigenous species between the 
TABLE 1. Presence/absence and richness of coccinellid species in Quebec perennial and annual crops.

\begin{tabular}{|c|c|c|c|c|c|c|c|c|c|c|c|}
\hline \multirow[b]{2}{*}{ Coccinellid species } & \multicolumn{6}{|c|}{ Perennial crops } & \multicolumn{5}{|c|}{ Annual crops } \\
\hline & $\begin{array}{l}\text { Pome } \\
\text { fruit }\end{array}$ & Grape & $\begin{array}{c}\text { Achillea } \\
\text { millefolium }\end{array}$ & $\begin{array}{c}\text { Echinacea } \\
\text { purpurea }\end{array}$ & $\begin{array}{l}\text { Hypericum } \\
\text { perforatum }\end{array}$ & $\begin{array}{l}\text { Valeriana } \\
\text { officinalis }\end{array}$ & $\begin{array}{c}\text { Sweet } \\
\text { corn }\end{array}$ & $\begin{array}{l}\text { Field } \\
\text { corn }\end{array}$ & $\begin{array}{l}\text { Sweet } \\
\text { pepper }\end{array}$ & $\begin{array}{l}\text { Let- } \\
\text { tuce }\end{array}$ & $\begin{array}{l}\text { Soy- } \\
\text { bean }\end{array}$ \\
\hline \multicolumn{12}{|l|}{ APHIDOPHAGOUS } \\
\hline Propylea quatuordecimpunctata L. & $+^{1}$ & + & + & + & - & + & + & + & + & + & + \\
\hline Coccinella septempunctata $\mathrm{L}$. & + & + & + & + & + & + & + & - & + & + & + \\
\hline Coleomegilla maculata lengi Timberlake & + & + & + & + & + & + & + & + & + & + & + \\
\hline Harmonia axyridis Pallas & + & + & + & + & + & + & + & + & + & + & + \\
\hline Adalia bipunctata $\mathrm{L}$. & + & - & - & - & - & - & + & - & - & - & - \\
\hline Coccinella trifasciata perplexa Mulsant & - & + & - & - & - & - & - & - & - & - & - \\
\hline Hippodamia parenthesis Say & + & + & - & - & - & - & - & - & - & - & + \\
\hline Hippodamia convergens Guérin & - & + & + & + & + & + & - & - & - & - & - \\
\hline Hippodamia variegata Goeze & - & + & - & - & - & - & - & - & - & - & + \\
\hline \multicolumn{12}{|l|}{ Coccidophagous } \\
\hline Brachyacantha ursina Fabricius & + & - & - & - & - & - & - & - & - & - & + \\
\hline Psyllobora vigintimaculata Say & + & + & - & - & - & - & - & - & - & - & - \\
\hline Hyperaspis binotata Say & + & - & - & - & - & - & - & - & - & - & - \\
\hline Hyperaspis undulata Say & + & - & - & - & - & - & - & - & - & - & - \\
\hline Chilocorus stigma Say & + & - & - & - & - & - & - & - & - & - & - \\
\hline Nephus flavifrons Melsheimer & + & - & - & - & - & - & - & - & - & - & - \\
\hline Richness & 12 & 9 & 5 & 5 & 4 & 5 & 5 & 3 & 4 & 4 & 7 \\
\hline
\end{tabular}

${ }^{1}(+)$ presence of the coccinellid species; $(-)$ absence.

different years (SAS Institute, 1996). When required, subsequent two-group G-tests were carried out.

\section{RESULTS}

\section{Pome fruit}

A total of 691 coccinellid specimens from 12 species of Coccinellidae were collected in $1999(\mathrm{n}=574)$ and 2000 $(\mathrm{n}=117)$ (Table 1). Six species were common to both years: Propylea quatuordecimpunctata (Linnaeus), Coccinella septempunctata Linnaeus, $H$. axyridis, Coleomegilla maculata lengi Timberlake and Brachyacantha ursina (Fabricius). They accounted for at least $20 \%$ of all captures. The relative proportion of the different species in the coccinellid assemblage significantly changed from 1999 to $2000\left(G_{4,682}=120.2 ; P<0.0001\right)$ (Fig. 1). In $1999, H$. axyridis represented the largest proportion with $64 \%$ of the assemblage, but this proportion decreased to $12 \%$ in 2000. Coleomegilla maculata lengi constituted $8 \%$ of the assemblage in 1999 , and it was the most common species in 2000 (30\%). Many coccidophagous species were also sampled in this orchard in 1999 and 2000. Brachyacantha ursina was one of the most prevalent species with 15 and $22 \%$ of total specimens in 1999 and 2000 respectively. The proportion of introduced coccinellids ( $P$. quatuordecimpunctata, C. septempunctata, H. axyridis) was $74.5 \%$ in 1999 and $33 \%$ in 2000 , a significant decrease $\left(G_{1,688}=76.1 ; P<0.0001\right)$.

\section{Grapes}

From 2000 to 2001, seven coccinellid species representing 88 specimens were collected from grapes (Table 1). No difference was observed in the relative proportion of the different species among the three years $\left(G_{8,76}=\right.$ 13.0; $P=0.112$ ). Coleomegilla maculata lengi was the prevalent aphidophagous species accounting for 58, 39 and $47 \%$ of specimens respectively in 2000, 2001 and 2002 (Fig. 1). The second most abundant species was $H$. axyridis with 17, 39 and $26 \%$ of the captures (Fig. 1). The percentage of introduced coccinellids represented $42 \%$ in $2000,51 \%$ in 2001 and $30 \%$ in $2002\left(G_{2,85}=2.8 ; P=\right.$ $0.250)$.

\section{Medicinal crops}

In A. millefolium, C. septempunctata comprised $39.6 \%$ of specimens, C. maculata lengi and Hippodamia convergens Guérin-Méneville each $25.4 \%$, whereas $H$. axyridis and $P$. quatuordecimpunctata each comprised $4.8 \%$ for a total of 63 coccinellids recorded. On E. purpurea 141 coccinellids were observed, among which $63.3 \%$ were $C$. maculata lengi, $16.7 \%$ were C. septempunctata, $10.0 \%$ were $H$. axyridis, $6.7 \%$ were $H$. convergens, and $3.3 \%$ were $P$. quatuordecimpunctata. On $H$. perforatum, 41 coccinellids were collected, represented by $73.2 \% \quad C$. maculata, $7.3 \%$ C. septempunctata, $4.9 \%$ H. axyridis, and $14.6 \% H$. convergens. On $V$. officinalis, 60 coccinellids were recorded during the summer, with $42.6 \% \mathrm{C}$. $\mathrm{macu}$ lata, $17 \%$ C. septempunctata, $16.3 \% H$. axyridis, $12.8 \%$ $H$. convergens, and $11.3 \%$ P. quatuordecimpunctata (Fig. 1). The percentage of introduced coccinellids on $A$. millefolium, E. purpurea, $H$. perforatum and $V$. officinalis represented $49.1,30.0,12.2$ and $44.6 \%$ respectively.

\section{Sweet corn}

In 2000, 1958 specimens from five species were recorded. The coccinellid assemblage was composed of $54.6 \%$ C. maculata, $23.4 \%$ P. quatuordecimpunctata, $11.7 \%$ C. septempunctata, $8.8 \% H$. axyridis and $1.5 \%$ Adalia bipunctata (Linnaeus) (Fig. 2). In 2001, the composition of the assemblage changed, with 4778 specimens belonging to four species $\left(G_{4,6728}=1204.15 ; P<0.001\right)$. 


\section{A) Pome fruit}

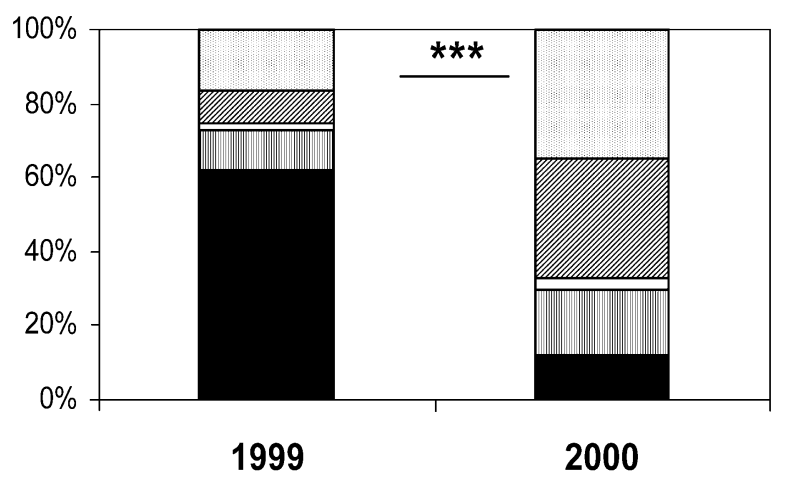

B) Grape

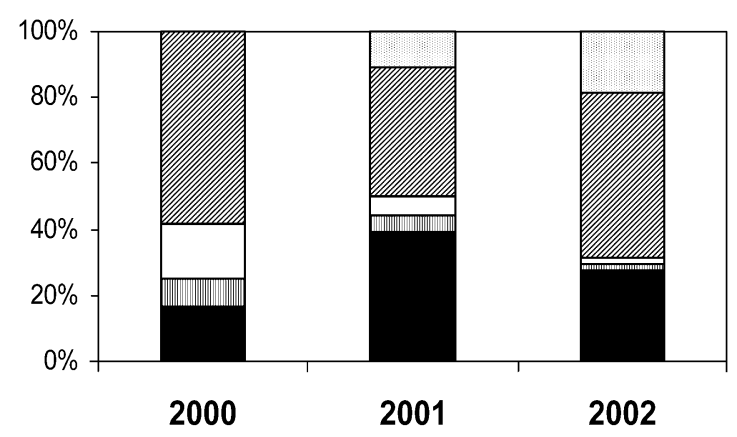

C) Medicinal crops

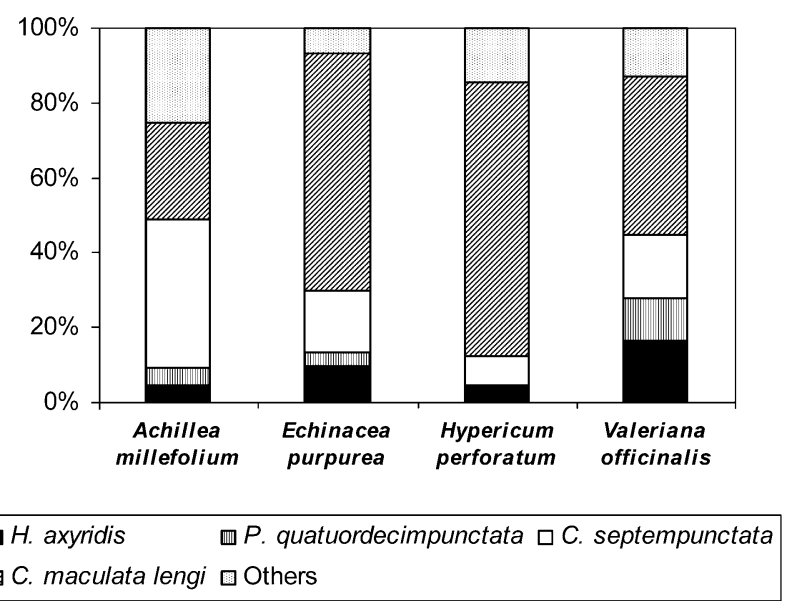

Fig. 1. Proportion of coccinellid species observed in Quebec perennial crops between 1999 and 2003. Note: * indicates $P<$ $0.05, * * P<0.01, * * * P<0.001$.

Harmonia axyridis was the most common species representing $49.2 \%$ of specimens followed by $C$. maculata (29.3\%), P. quatuordecimpunctata (11.6\%) and C. septempunctata $(9.9 \%)$. The percentage of introduced coccinellids significantly increased from $43.9 \%$ in 2000 to $70.7 \%$ in $2001\left(G_{1,6734}=419.9 ; P<0.001\right)$.

\section{Field corn}

In 2002, 1053 specimens were collected during the summer. Propylea quatuordecimpunctata represented $5.7 \%$, C. maculata $39.3 \%$, and $H$. axyridis $55.4 \%$ of sam- ples (Fig. 2). In 2003, a total of 681 specimens of the same three species were recorded. The relative proportion of the species changed significantly in 2003 with $9.7 \%$ for P. quatuordecimpunctata, $73.6 \%$ for C. maculata and $16.7 \%$ for $H$. axyridis $\left(G_{2,1730}=271.68 ; P<0.001\right)$. The percentage of introduced coccinellids changed from $61.1 \%$ in 2002 to $26.4 \%$ in $2003\left(G_{1,1732}=202.80 ; P<\right.$ $0.001)$.

\section{Sweet pepper}

During July and August 2002, 109 adult coccinellids from four different species were collected on more than 1800 plants; C. maculata represented $34 \%$ of samples, $H$. axyridis $42.2 \%$, P. quatuordecimpunctata $14.7 \%$ and $C$. septempunctata $9.1 \%$ (Fig. 2). No sampling was carried out in September because the grower applied pesticides following an aphid outbreak. The percentage of introduced coccinellids was $66.1 \%$.

\section{Lettuce}

In 2002, 180 individuals of four different species were collected. Harmonia axyridis represented $20 \%$ of the assemblage, $P$. quatuordecimpunctata $25 \%$, C. septempunctata $20 \%$ and C. maculata $35 \%$ (Fig. 2). Adults and larvae of the species were observed during the sampling. The percentage of introduced coccinellids represented $65 \%$.

\section{Soybean}

In 2002, 265 specimens from six coccinellid species were identified: $65 \%$ were $P$. quatuordecimpunctata, $3 \%$ were $C$. septempunctata, $21.1 \%$ were $H$. axyridis and $9 \%$ were $C$. maculata. Hippodamia variegata Goeze and $H$. parenthesis Say represented the remaining $1.9 \%$ of other species. In 2003, a total of 69 specimens (seven species) of coccinellids were identified (Fig. 2). The relative proportion of the different species changed with $53.6 \%$ for $P$. quatuordecimpunctata, $13 \%$ for $C$. septempunctata, $20.3 \%$ for $H$. axyridis and $7.3 \%$ for $C$. maculata $\left(G_{4,326}=\right.$ $12.5 ; P=0.014)$. Other species (H. variegata, $H$. parenthesis and $B$. ursina) represented the remaining 5.8\%. The percentage of introduced coccinellids was $89.1 \%$ in 2002 and $87 \%$ in $2003\left(G_{1,359}=0.17 ; P=0.683\right)$.

\section{DISCUSSION}

The results of this study indicate that seven to ten years after its arrival, $H$. axyridis is clearly one of the dominant coccinellid species in most crops of Eastern Canada. This invasive species was observed in three perennial and five annual monitored crops (Table 1). Other unpublished data from the same area indicated that this coccinellid is also present in raspberry, canola, and celery. In raspberry for example, $H$. axyridis represented $1.1 \%$ of the coccinellids collected in 1995 and $18.7 \%$ in 1996, out of a total of 374 and 916 specimens collected, respectively (Roy, unpubl. data). In soybean, the arrival of this coccinellid coincided with the arrival of the soybean aphid, Aphis glycines Matsumura (Fox et al., 2004; Mignault et al., 2006). Our study reports results from several agroecosystems, where the species is well adapted. However, its eurytopic habits include forest and other natural systems (Tedders \& 
A) Sweet Corn

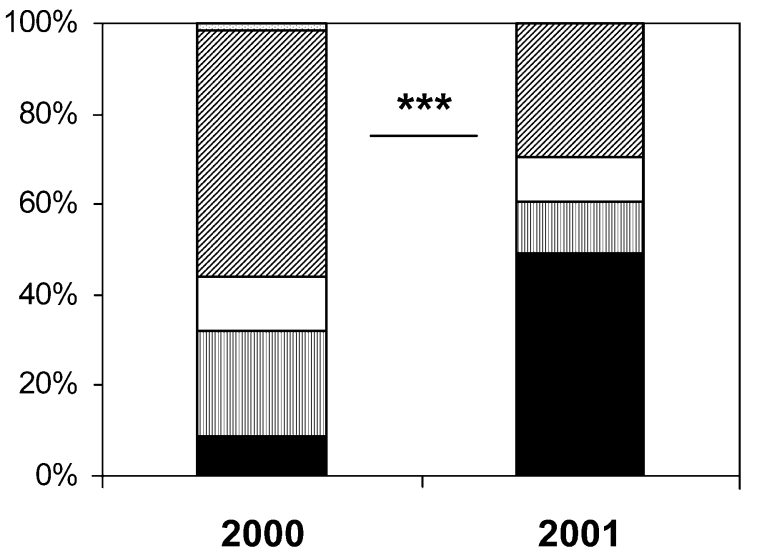

C) Lettuce \& sweet pepper

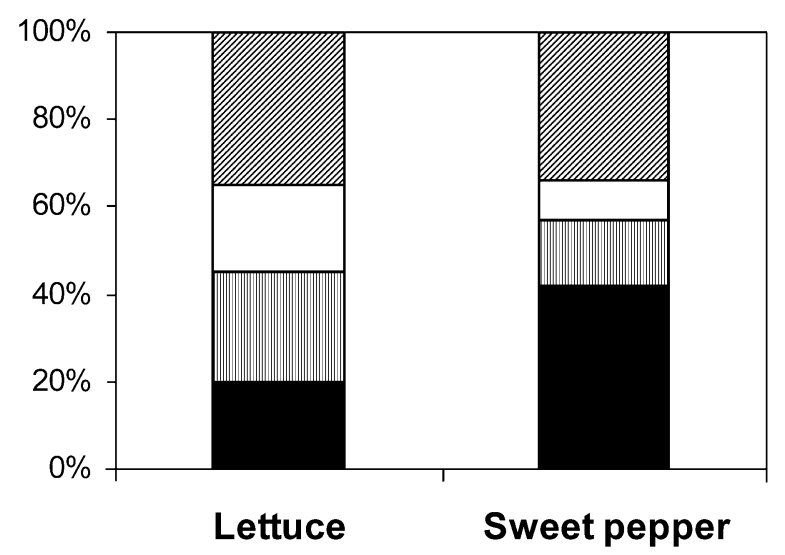

B) Field corn

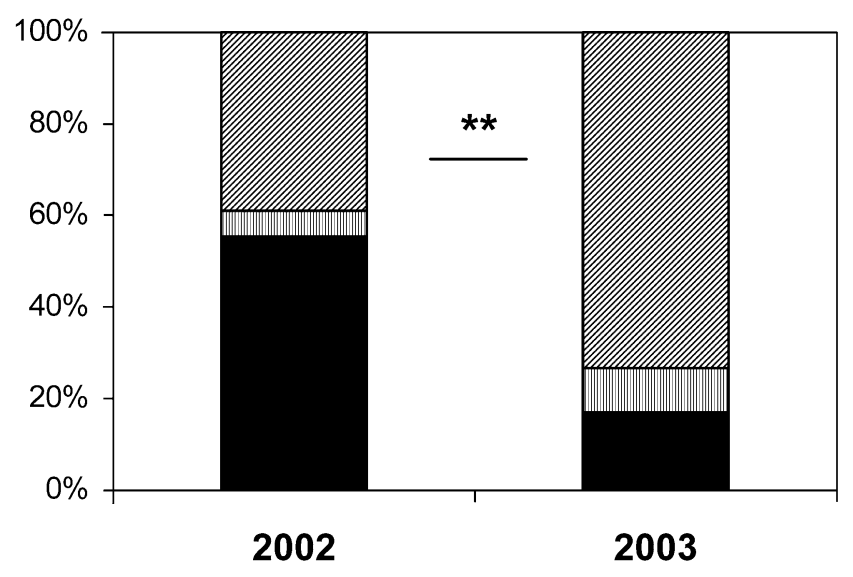

D) Soybean

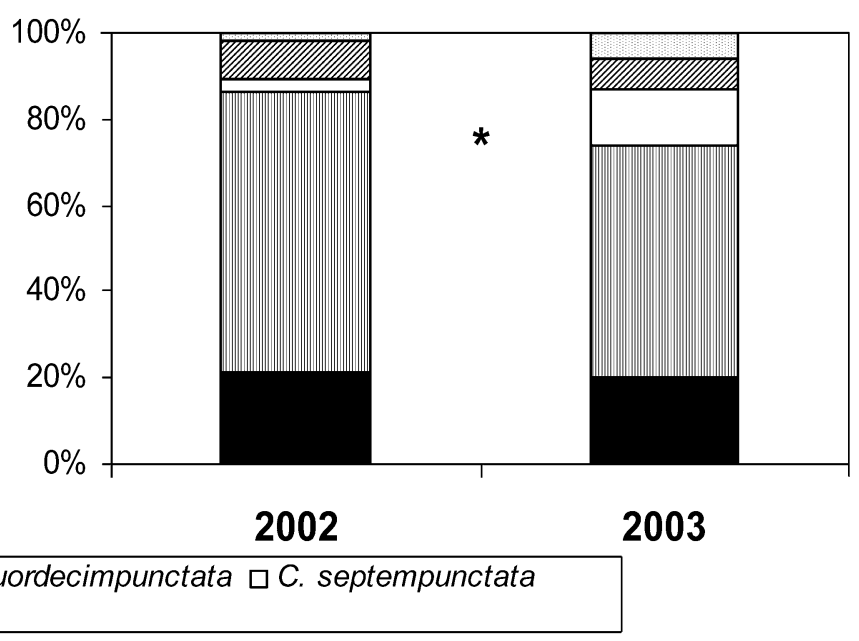

Fig. 2. Proportion of coccinellid species observed in Quebec annual crops between 2000 and 2003. Note: * indicates $P<0.05$, ** $P<0.01, * * * P<0.001$.

Schaefer, 1994). The species has also been observed on aspen, birch, willow and fir (Berthiaume et al., 2000). It has also been observed in swamp ecosystems and urban areas (e.g. Montreal, Canada). Geographically, this invader is reported throughout southern Quebec and as far North as Abitibi $\left(48^{\circ} 30^{\prime} \mathrm{N}, 77^{\circ} 47^{\prime} \mathrm{W}\right)$. This colonization reflects a huge success for this invasive species.

In all monitored crops, nine aphidophagous and six coccidophagous species were observed (Table 1). Highest richness was observed in perennial crops (pome fruit, grape), where the coccidophagous species were almost exclusively observed (except for soybean, where one individual of $B$. ursina was observed in 2003). Among the aphidophagous species, three invasive ( $H$. axyridis, $C$. septempunctata and $P$. quatuordecimpunctata) were consistently present, as well as one indigenous species $(C$. maculata) (Table 1). While for a given crop, relative proportion of coccinellid species varied between years (Fig. $1,2)$, these invasive species actually represented between 12 to $89 \%$ of the coccinellids encountered. Some annual crops presented very high proportion of invasive species, such as soybean, with 89 and $87 \%$ of invasive species, in 2002 and 2003 respectively (Fig. 2D). These three invasive species are polyphagous predators attacking a great diversity of prey including aphids, mites, scales, and lepidopteran and coleopteran larvae (Hodek \& Honěk, 1996). They are also eurytopic species, exploiting a great diversity of habitats. Consequently, they may have caused considerable changes in various ecosystems. For example, in 1978 , indigenous species represented $100 \%$ of the coccinellid assemblage in southern Quebec field corns. The coccinellids comprised 74.5\% Hippodamia tredecimpunctata tibialis (Say) and 24.1\% C. maculata (Coderre, unpubl. data). For over five years now, $H$. tredecimpunctata tibialis has completely disappeared from the corn fields. While in our study the highest abundance of aphidophagous coccinellids was observed in sweet and field corn, three invasive ( $H$. axyridis, $C$. septempunctata and $P$. quatuordecimpunctata) and only one indigenous $(C$. maculata) species were present, suggesting high incidence of invasive coccinellid species in corn fields. 
Brown \& Miller (1998) and Lucas et al. (2002) showed that a species may be more susceptible to impact by an invader than other species because of their common spatial niche in the ecosystem. Other indigenous species such as $C$. maculata were thought to be affected by the presence of $H$. axyridis (Musser \& Shelton, 2003; Hoogendoorn \& Heimpel, 2004). However, our study showed the continued presence of the indigenous $C$. maculata along with the three introduced ladybeetles in each agroecosystem examined. Coleomegilla maculata is found on the lower parts of corn plants and avoids competition with $H$. axyridis which is found on the upper parts of plants (Musser \& Shelton, 2003). As a result of this niche partitioning, $C$. maculata is able to coexist with $H$. axyridis in corn fields, suggesting that this species may not suffer adversely from the presence of these invasive species in the future.

The multicolored Asian ladybeetle is now well established in most crops and agro-ecosystems in Canada and USA. Several crops monitored in our study presented a predominant proportion of $H$. axyridis in the different years of the study (Figs 1,2). The arrival of the multicolored Asian ladybeetle has been associated with significant changes in native guild structures (Tedders \& Schaeffer, 1994; LaMana \& Miller, 1996; Brown \& Miller, 1998; Michaud, 2002; Snyder et al., 2004). The consequences of such an invasion may also adversely affect other natural enemies of aphids such as hover flies, lacewings, gall midges, and hemipteran predators by exploitative competition and intraguild predation (Horn, 1991; Koch et al., 2003; Lucas et al., 2007). High abundance and presence of the multicolored Asian ladybeetle and two other invasive species suggest their adverse impact on indigenous species. As agroecosystems may be subjected to several dynamic processes, including potential invasion by other coccinellid species, our results should be revisited in the context of a longer term study (over 20 years after invasion).

ACKNOWLEDGMENTS. This research was supported by NSERC scholarship for G. Labrie, NSERC grant to D. Coderre and E. Lucas. The authors express their gratitude to the late V. Dietrich, C. Jooss and C.-H. de Coussergues proprietors of Dietrich-Jooss and L'Orpailleur vineyards. B. Rancourt, J. Bellemare, and M. Trudeau are also thanked for their participation in the study. L. Lesage confirmed the identification of specimens. The vineyard study, co-financed by Agriculture and AgriFood Canada and Dietrich-Jooss and L'Orpailleur vineyards, was granted to N.J. Bostanian and C. Vincent (MII project AAC\# 97-5735). We also thank M. Roy, M.-L. Pelletier and S. Tremblay for unpublished data on the multicolored Asian ladybeetle.

\section{REFERENCES}

Berthiaume R., Hébert C. \& Cloutier C. 2000: Predation on Mindarus abietinus infesting balsam fir grown as Christmas trees: the impact of coccinellid larval predation with emphasis on Anatis mali. BioControl 45: 425-438.

Bostanian N.J., Vincent C., Goulet H., Lesage L., Lasnier J., Bellemare J. \& Mauffette Y. 2003: The arthropod fauna of Quebec vineyards with particular reference to phytophagous arthropods. J. Econ. Entomol. 96: 1221-1229.
BRown M.W. 2003: Intraguild responses of aphid predators on apple to the invasion of an exotic species, Harmonia axyridis. BioControl 48: 141-153.

Brown M.W. \& Miller S.S. 1998: Coccinellidae (Coleoptera) in apple orchards of eastern West Virginia and the impact of invasion by Harmonia axyridis. Entomol. News 109: 143-151.

Chapin J.B. \& Brou V.A. 1991: Harmonia axyridis (Pallas), the third species of the genus to be found in the United States (Coleoptera: Coccinellidae). Proc. Entomol. Soc. Wash. 93: 630-635.

Coderre D., Lucas E. \& Gagné I. 1995: The occurrence of Harmonia axyridis (Pallas) (Coleoptera, Coccinellidae) in Canada. Can. Entomol. 127: 609-611.

Colunga-Garcia M. \& Gage S.H. 1998: Arrival, establishment, and habitat use of the multicolored Asian lady beetle (Coleoptera: Coccinellidae) in a Michigan landscape. Environ. Entomol. 27: 1574-1580.

Dixon A.F.G. 2000: Insect Predator-Prey Dynamics: Ladybird Beetles and Biological Control. Cambridge University Press, Cambridge, UK, 257 pp.

Elliott N., KieckHefer R. \& Kauffman W. 1996: Effects of an invading coccinellid on native coccinellids in an agricultural landscape. Oecologia 105: 537-544.

Ellis D.R. Prokrym D.R. \& Adams R.G. 1999: Exotic lady beetle survey in northeastern United States: Hippodamia variegata and Propylea quatuordecimpunctata (Coleoptera: Coccinellidae). Entomol. News 110: 73-84.

Evans E.W. 2004: Habitat displacement of North American ladybirds by an introduced species. Ecology 85: 637-647.

Fox T.B., Landis D.A., Cardoso F.F. \& Difonzo C.D. 2004: Predators suppress Aphis glycines Matsumura population growth in soybean. Environ. Entomol. 33: 608-618.

GoRDOn R.D. 1985: The Coccinellidae (Coleoptera) of America north of Mexico. J. N. Y. Entomol. Soc. 93: 1-912.

GoRDON R.D. \& VANDENBERG N. 1991: Field guide to recently introduced species of Coccinellidae (Coleoptera) in North America, with a revised key to North American genera of Coccinellini. Proc. Entomol. Soc. Wash. 93: 845-864.

HewitT C.L. \& Huxel G.R. 2002: Invasion success and community resistance in single and multiple species invasion models: do the models support the conclusions? Biol. Invas. 4: 263-271.

Hironori Y. \& Katsuhiro S. 1997: Cannibalism and interspecific predation in two predatory ladybirds in relation to prey abundance in the field. Entomophaga 42: 153-163.

Hodek I. \& HonĚK A. 1996: Ecology of Coccinellidae. Kluwer Academic Publishers, Dordrecht, 464 pp.

Hoogendoorn M. \& Heimpel G.E. 2004: Competitive interactions between an exotic and a native ladybeetle: a field cage study. Entomol. Exp. Appl. 111: 19-28.

HoRN D.J. 1991: Potential impact of Coccinella septempunctata on endangered Lycaenidae (Lepidoptera) in Northwestern Ohio, USA. In Polgar L., Chambers R.J., Dixon A.F.G. \& Hodek I. (eds): Behaviour and Impact of Aphidophaga. SPB Academic Publishing, The Hague, pp. 159-162.

IABloKoff-Khnzorian S.M. 1982: Les Coccinelles, Coléoptères - Coccinellidae. Société Nouvelle des Éditions Boubée, Paris, $568 \mathrm{pp}$.

Kajita Y., Takano F., Yasuda H. \& Agarwala B.K. 2000: Effects of indigenous ladybird species (Coleoptera: Coccinellidae) on the survival of an exotic species in relation to prey abundance. Appl. Entomol. Zool. 35: 473-479.

KocH R.L. 2003: The multicolored Asian lady beetle, Harmonia axyridis: A review of its biology, uses in biological control, and non-target impacts. J. Insect Sci. 3: 1-16. 
Кoch R.L., Hutchison W.D., Venette R.C. \& Heimpel G.E. 2003: Susceptibility of immature monarch butterfly, Danaus plexippus (Lepidoptera: Nymphalidae: Danainae), to predation by Harmonia axyridis (Coleoptera: Coccinellidae). Biol. Control 28: 265-270.

Labrie G., Coderre D. \& Lucas E. 2007: Overwintering strategy of the multicolored Asian ladybeetle (Coleoptera: Coccinellidae): a cold-free space as a factor of invasive success. Ann. Entomol. Soc. Am. (in press).

LaMana M.L. \& Miller J.C. 1996: Field observations on Harmonia axyridis Pallas (Coleoptera: Coccinellidae) in Oregon. Biol. Control 6: 232-237.

Larochelle A. 1979: Les Coléoptères Coccinellidae du Québec. Cordulia (Suppl.) 10: 1-111.

LucAs E., CoderRe D. \& Vincent C. 1997: Voracity and feeding preferences of two aphidophagous coccinellids on Aphis citricola and Tetranychus urticae. Entomol. Exp. Appl. 85: 151-159.

Lucas E., Coderre D. \& Brodeur J. 1998: Intraguild predation among aphid predators: characterization and influence of extraguild prey density. Ecology 79: 1084-1092.

LuCAS E., Gagné I. \& CODERRE D. 2002: Impact of the arrival of Harmonia axyridis on adults of Coccinella septempunctata and Coleomegilla maculata (Coleoptera: Coccinellidae). Eur. J. Entomol. 99: 457-463.

Lucas E., Demougeot S., Vincent C. \& Coderre D. 2004: Effect of the presence of a second prey species on the voracity of Coccinella septempunctata and Harmonia axyridis (Coleoptera: Coccinellidae). Eur. J. Entomol. 101: 37-41.

Lucas E., Labrie G., Vincent C. \& Kovach J. 2007: The multicolored Asian ladybeetle, Harmonia axyridis - beneficial or nuisance organism? In Vincent C., Goettel M. \& Lazarovitz G. (eds): Case Studies in Biological Control: A Global Perspective. CABI Publishing, Wallingford, pp. 38-52.

Majerus M., Strawson V. \& Roy H. 2006: The potential impacts of the arrival of the harlequin ladybird, Harmonia axyridis (Pallas) (Coleoptera: Coccinellidae), in Britain. Ecol. Entomol. 31: 207-215.

Michaud J.P. 2002: Invasion of the Florida citrus ecosystem by Harmonia axyridis (Coleoptera: Coccinellidae) and asymmetric competition with a native species, Cycloneda sanguinea. Environ. Entomol. 31: 827-835.
Mignault M.-P., Roy M. \& Brodeur J. 2006: Soybean aphid predators in Québec and the suitability of Aphis glycines as prey for three Coccinellidae. BioControl 51: 89-106.

Musser F.R. \& Shelton A.M. 2003: Factors altering the temporal and within-plant distribution of coccinellids in corn and their impact on potential intraguild predation. Environ. Entomol. 32: $575-583$.

Pervez A.O. \& OmKar 2006: Ecology and biological control application of multicoloured Asian ladybird, Harmonia axyridis: a review. Biocont. Sci. Tech. 16: 111-128.

SAS InSTITUTE. 1996: “JMP In, version 3.2.” SAS Institute Inc., Cary, North Carolina.

Shea K. \& Chesson P. 2002. Community ecology theory as a framework for biological invasions. Trends Ecol. Evol. 17: $170-176$.

Snyder W.E., Clevenger G.M. \& Eigenbrode S.D. 2004: Intraguild predation and successful invasion by introduced ladybird beetles. Oecologia 140: 559-565.

Stachowicz J.J., Fried H., Osman R.W. \& Whitlatch R.B. 2002: Biodiversity, invasion resistance, and marine ecosystem function: reconciling pattern and process. Ecology 83: 2575-2590.

Tedders W.L. \& Schaefer P.W. 1994: Release and establishment of Harmonia axyridis (Coleoptera, Coccinellidae) in the Southeastern United-States. Entomol. News 105: 228-243.

Turnock W.J., Wise I.L. \& Matheson F.O. 2003: Abundance of some native coccinellines (Coleoptera: Coccinellidae) before and after the appearance of Coccinella septempunctata. Can. Entomol. 135: 391-404.

Wheeler A.G. \& HoebeKe E.R. 1995: Coccinella novemnotata in northeastern North America: Historical occurrence and current status (Coleoptera: Coccinellidae). Proc. Entomol. Soc. Wash. 97: 701-716.

Yasuda H. \& OHNuma N. 1999: Effect of cannibalism and predation on the larval performance of two ladybird beetles. Entomol. Exp. Appl. 93: 63-67.

Yasuda H., Kikuchi T., Kindlmann P. \& Sato S. 2001: Relationships between attack and escape rates, cannibalism, and intraguild predation in larvae of two predatory ladybirds. $J$. Insect Behav. 14: 373-384.

Received May 11, 2007; revised and accepted July 11, 2007 